\title{
ESTIMASI STATE-OF-CHARGE MENGGUNAKAN SIMULINK PADA BATERAI PEMBANGKIT LISTRIK TENAGA SURYA
}

\author{
Bambang Sugeng 1), Riza Hadi Saputra ${ }^{2)}$ \\ ${ }^{1,2)}$ Sekolah Tinggi Teknologi Minyak dan Gas Bumi Balikpapan \\ e-mail: bas.sugeng@gmail.com ${ }^{1)}$, riza.hadi@gmail.com ${ }^{2)}$
}

\begin{abstract}
Indonesia is currently in an energy crisis situation where demand is more than energy available. This is also be affected by increasingly modern technology that will increasingly require electricity. Therefore, currently research is also on renewable energy which can help conventional electricity companies. One such renewable energy is a solar power plant, where solar energy is absorbed into solar cells in the form of photons, which when this energy hits the surface of solar cells, the electrons will be excited and cause electricity. But, not only the components of solar cells that exist in solar power plants, there are several parts, one of which is a battery as a storage place for electricity. Batteries's role is very important in solar power plants. If the battery is not properly monitored, the performance of battery can decrease gradely and this continues will decrease perfor-mance for solar cell. There are several parameters that can affect battery performance, one of which is SOC (State-of-Charge). The aim of this study is to determine the SOC estimation with the MATLAB application and SIMULINK modeling. The results are obtained that the battery works in the 30\% SOC range for the lower limit and 90\% for the upper limit by assuming the used battery is a new battery that has not submit to many charge and discharge cycles.
\end{abstract}

Keywords: Solar Cell, Batteries, State-of-Charge, MATLAB, SIMULINK.

\begin{abstract}
ABSTRAK
Sudah tidak bisa ditutupi lagi bahwa saat ini Indonesia sedang krisis energi dimana permintaan lebih banyak daripada pemasokan energi listrik. Hal ini juga diiringi dengan semakin canggih teknologi akan semakin banyak membutuhkan energi listrik. Oleh karena itu, saat ini juga sedang disibukkan penelitian tentang energi terbarukan dimana bisa membantu perusahaan energi listrik konvensional. Salah satu energi terbarukan tersebut adalah pembangkit listrik tenaga surya, dimana energi cahaya matahari yang terserap ke sel surya dalam bentuk foton yang ketika energi ini mengenai permukaan sel surya, maka elektronnya akan tereksitasi dan menimbulkan aliran listrik. Namun tidak hanya komponen sel surya yang ada pada pembangkit listrik tenaga surya, ada beberapa bagian yang salah satunya adalah baterai sebagai tempat penyimpanan listrik. Baterai sangat berperan penting dalam pembangkit listrik tenaga surya. Jika baterai tidak diawasi dengan benar, maka baterai dapat mengalami penurunan performansi dan hal ini berkesinambungan dengan penurunan performansi dari sel surya. Ada beberapa parameter yang dapat mempengaruhi performansi bat-erai yang salah satunya adalah SOC (State-ofCharge). Dalam penelitian ini bertujuan untuk mengetahui es-timasi SOC dengan aplikasi MATLAB dan pemodelan SIMULINK. Hasil yang didapatkan adalah baterai bekerja pada rentang SOC 30\% untuk batas bawah dan $90 \%$ untuk batas atas dengan asumsi baterai yang digunakan adalah baterai baru yang belum me-ngalami banyak siklus pengisian dan pengosongan.
\end{abstract}

Kata Kunci: Sel Surya, Baterai, State-of-Charge, MATLAB, SIMULINK.

\section{I.PENDAHULUAN}

$\mathrm{P}$ EMAKAIAN energi listrik di Indonesia semakin lama semakin bertambah. Hal ini dikarenakan karena meningkatnya permintaan konsumen dalam penggunaan energi listrik [1]. Peningkatan kebutuhan tersebut diiringi oleh kemajuan teknologi saat ini. Mau tidak mau, pemerintah harus berperan untuk membuat energi terbarukan dimana energi terbarukan ini digunakan untuk membantu dalam memenuhi kebutuhan energi listrik yang dikelola oleh perusahaan energi listrik konvensional sekarang [2]. Ada berbagai macam energi terbarukan yang tersedia seperti energi air, energi angin, energi matahari, dan energi terbarukan lainnya. Pembangkit listrik tenaga surya adalah 
pembangkit listrik yang dihasilkan dari energi sinar matahari yang diubah ke dalam energi listrik [3]. Pembangkit listrik tenaga surya sendiri terdiri dari beberapa bagian diantaranya adalah bagian penghasilan, bagian pengkonversian, dan bagian penyimpanan. Bagian penghasilan adalah panel surya sedangkan bagian pengkonversian adalah inverter, dan bagian penyimpanan adalah baterai [4]. Bagian penghasilan adalah bagian yang berfungsi menghasilkan listrik dengan cara menyerap energi sinar matahari menjadi listrik. Untuk bagian pengkonversian adalah bagian yang berfungsi mengubah arus dan tegangan yang searah menjadi dua arah atau bolak-balik [5]. Yang terakhir adalah bagian penyimpanan yaitu menyimpan energi listrik yang telah dihasilkan ke dalam baterai. Dari ketiga bagian tersebut, yang paling kritikal adalah bagian penyimpanan karena bagian ini yang mudah rusak jika tidak dirawat dengan baik [6]. Banyak faktor yang menyebabkan baterai bisa rusak dengan cepat diantaranya adalah siklus yang tidak teratur.

Baterai mempunyai performansi yang dapat mempengaruhi sistem. Dua hal penting dalam penggunaan baterai yaitu siklus pengisian dan siklus pengosongan [7]. Siklus pengisian dan pengosongan yang tidak tepat dapat mengurangi umur baterai secara cepat [8]. Oleh karena itu, perlunya pengawasan pada baterai untuk memperhatikan secara teliti kedua siklus tersebut. Ada beberapa indikator penting yang terdapat pada baterai yang salah satunya adalah State of Charge (SOC). SOC adalah kondisi kapasitas baterai pada saat itu dimana lebih dikenal dalam satuan persen (\%) yang tercantum di setiap perangkat elektronik yang ada [9]. Metode untuk mengestimasi SOC ada bermacammacam yang salah satunya adalah metode perhitungan Coulomb. Perhitungan Coulomb adalah sebuah metode yang mengukur kapasitas baterai dengan membandingkan arus yang keluar dan masuk pada baterai [10]. Dalam penelitian ini menggunakan metode coulomb counting dengan bantuan MATLAB sebagai media simulasi untuk mendapatkan nilai estimasi SOC pada baterai pembangkit listrik tenaga surya.

\section{MEtode PenELITIAN}

Dalam penelitian ini, metode penelitian yang dilakukan dimulai dari instalasi alat, pengambilan data pada sel surya, pengolahan data, simulasi pada MATLAB, dan mengambil kesimpulan dari hasil penelitian. Untuk lebih jelasnya, berikut pada Gambar 1. adalah tahapan penelitian yang telah dilakukan.

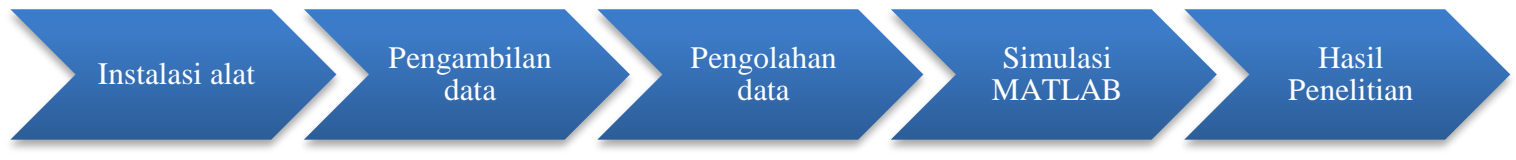

Gambar 1. Prosedur Penelitian

\section{A. Instalasi Alat}

Dalam penelitian ini, yang perlu dipersiapkan adalah mempersiapkan rangka sel surya, mempersiapkan instalasi kabel dari sensor ke sel surya, dan mempersiapkan instalasi kabel dari sensor ke laptop. Dalam hal ini, rangka sel surya yang dibuat adalah hasil dari desain penulis sehingga pembuatannya pun dilakukan secara manual seperti yang terlihat pada Gambar 2 .

Kerangkan yang dibuat menggunakan bahan besi dengan cat abu-abu dengan dimensi $120 \times 70 \times 70$ (dalam satuan centimeter). Bentuk ukuran kerangka yang dibuat adalah berbentuk meja yang berfungsi sebagai dudukan dari sel surya dengan sudut yang bisa diatur tingkat derajatnya. Dalam penelitian ini menggunakan sudut $40^{\circ}$ derajat karena pada sudut tersebut cahaya matahari yang didapatkan bisa maksimal mengacu pada jalur matahari bergerak.

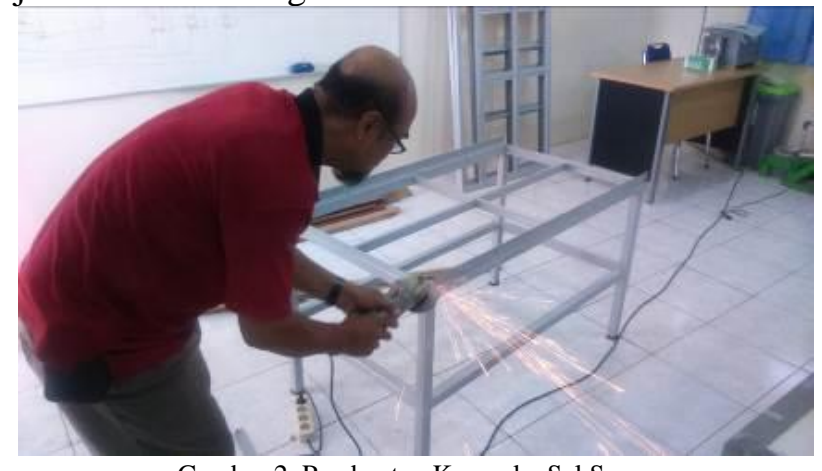

Gambar 2. Pembuatan Kerangka Sel Surya 
Setelah kerangka sel surya sudah selesai dibuat, maka selanjutnya adalah instalasi kabel dari sensor ke sel surya dimana sensor yang digunakan adalah sensor tegangan dan sensor arus. Untuk koneksi kabel dari sel surya ke sensor dibutuhkan kabel sepanjang 20 meter dikarenakan area pengambilan data berada di dua tempat yang jauhnya sekitar 20 meter, yaitu sel surya berada di lantai dasar atau lantai 1 (di jalan kampus) sedangkan sensor berada di lantai 2. Untuk lebih jelasnya, berikut pada Gambar 3. adalah instalasi kabel sel surya ke sensor dan ke laptop. dan Gambar 4. adalah letak sel surya pada saat pengambilan data.

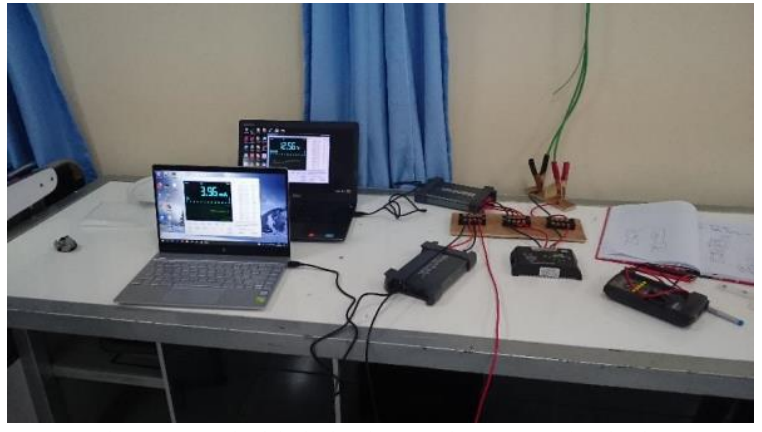

Gambar 3. Instalasi kabel sel surya ke sensor dan ke laptop

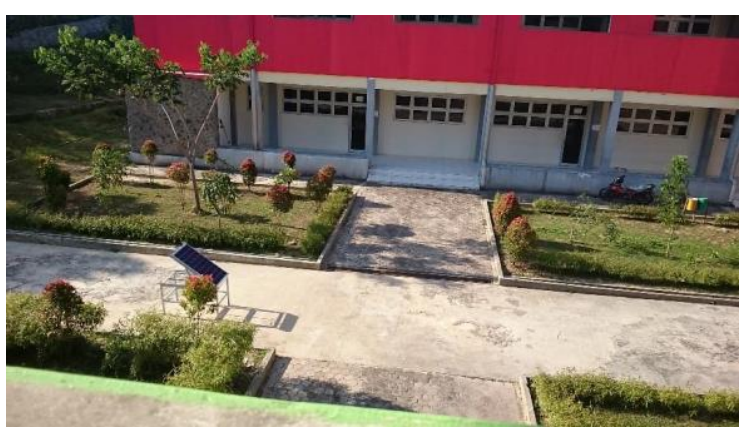

Gambar 4. Letak sel surya

\section{B. Pengambilan Data}

Pengambilan data dilakukan dua cara yaitu pada saat pengisian dan pada saat pengosongan. Langkah awal yang dilakukan adalah melakukan proses pengisian dimana baterai yang digunakan masih dalam keadaan belum penuh sehingga diharuskan diisi terlebih dahulu sebelum digunakan atau dikosongkan. Untuk data yang diambil adalah tegangan dan arus yang berasal dari sel surya. Dalam hal ini digunakan masing - masing sensor untuk mengambil datanya agar data yang didapatkan maksimal. Sensor yang digunakan dalam pengambilan data ini menggunakan Sensor merek HANTEK 365 dimana sensor ini dapat membaca dan mengambil data tegangan dan arus baterai dengan akurat. Untuk pemasangan sensor ini ditempatkan diantara jalan sel surya menuju baterai. Solar Charge Controller berfungsi untuk mengatur tegangan dan arus yang diterima dari sel surya sebelum masuk ke dalam baterai. Berikut pada Gambar 5 adalah sistem dari rangkaian sensor yang telah terhubung oleh sel surya melalui solar charge controller.

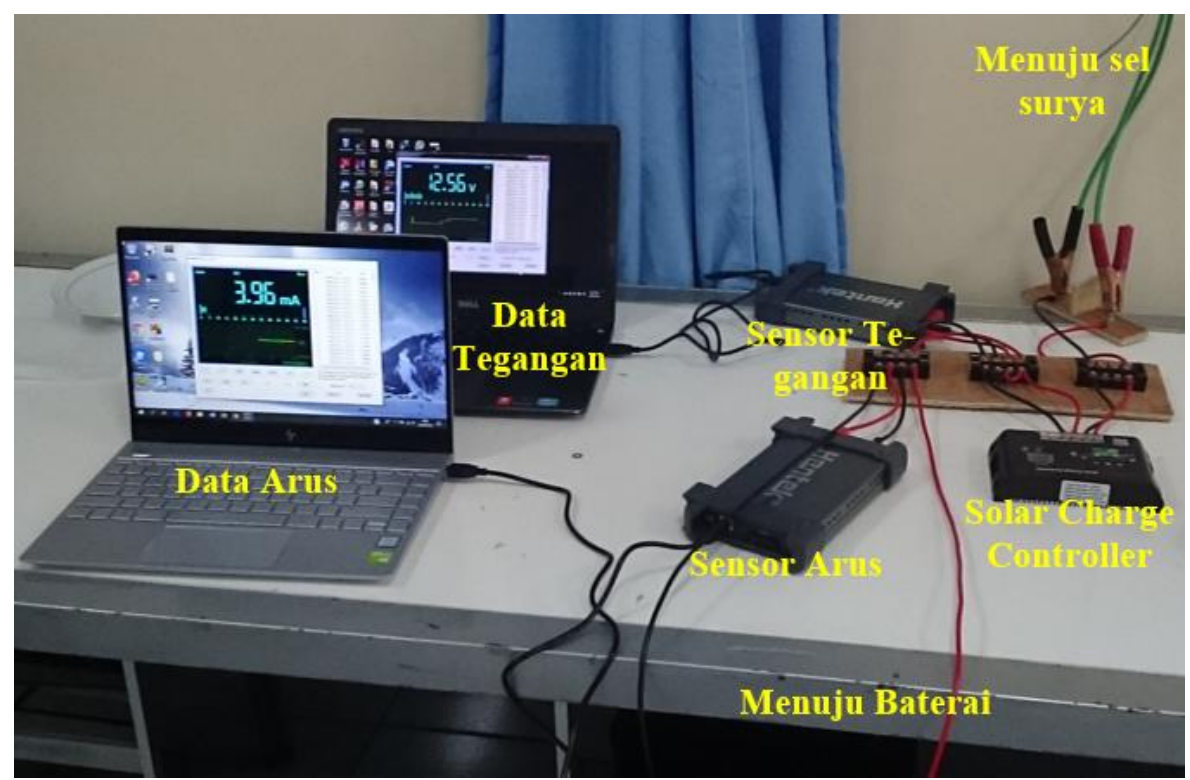

Gambar 5. Sistem Rangkaian Sensor

Selanjutnya adalah pengambilan pada saat pengosongan dimana syarat utama yang harus dilakukan pada saat melakukan pengosongan baterai adalah baterai harus dalam keadaan penuh atau nilai kapasitasnya adalah $100 \%$. Pengosongan baterai dilakukan dengan beban adalah lampu pijar $60 \mathrm{watt}$ 
dengan tegangan $220 \mathrm{VAC}$. Oleh karena itu, digunakan inverter $D C$-to- $A C$ dengan spesifikasi 500 WATT dalam penelitian ini agar tegangan listrik yang ada pada baterai dapat digunakan oleh beban. Sama seperti pengisian, untuk pengosongan dilakukan secara terpisah yaitu kondisi pada saat pengosongan adalah tidak mengikutsertakan sel surya yang sebelumnya terpasang. Untuk lebih jelasnya akan ditampilkan pada Gambar 6 mengenai sistem pengosongan baterai.

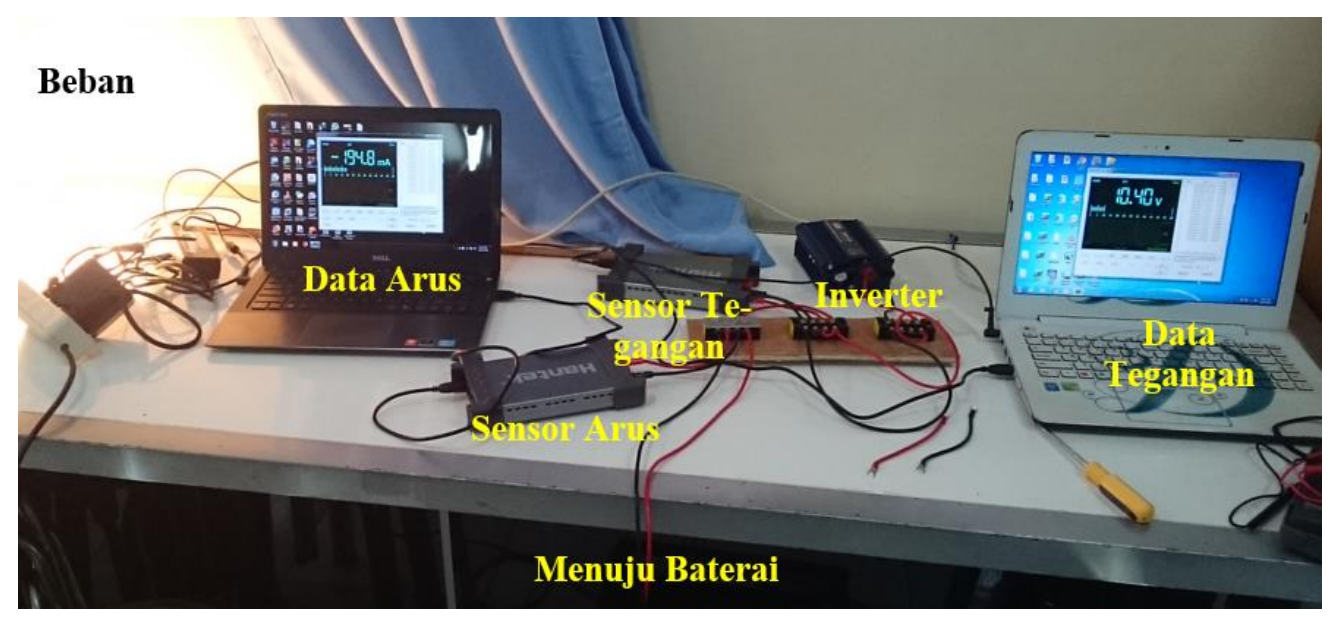

Gambar 6. Sistem Rangkaian pada saat Pengosongan Baterai

\section{HASIL DAN PEMBAHASAN}

Setelah data didapatkan, maka data tersebut diolah ke dalam suatu program bantuan untuk kalkulasi yaitu MATLAB. Data yang dimasukkan ke dalam MATLAB adalah data pengisian dan data pengosongan yang telah didapatkan dari hasil percobaan [11]. Data tegangan dan arus diperoleh dari aplikasi sensor HANTEK 365 dimana data tersebut dipindahkan ke dalam Microsoft Excel untuk diolah. Dari olahan data tersebut, maka didapatkan nilai rata-rata tegangan dan arus yang dilakukan selama 7 hari. Dari data tersebut lalu dimasukkan ke dalam MATLAB sebagai batasan untuk simulasi sel surya yang disimpan ke dalam baterai selama 14 bulan atau 10080 jam. Simulasi selama 14 bulan dilakukan karena waktu tersebut adalah waktu dimana sel surya 100 WP mengisi baterai kapasitas 100 Ah sampai penuh dengan arus listrik konstan. Hal ini juga berlaku untuk sistem pengosongan dimana beban yang digunakan disimulasikan dengan MATLAB.

Kapasitas yang didapatkan dari sel surya pada saat pengisian selama 7 hari (7 kali pengambilan data) dengan cuaca cerah maupun mendung adalah sekitar 0,2 Ah per hari dengan total 1,4 Ah selama 7 hari. Hal ini dikarenakan sedikitnya kapasitas tenaga sel surya yaitu hanya $100 \mathrm{WP}$ untuk mengisi baterai yang besarnya 100 Ah. Selain itu, cuaca yang tidak selalu cerah di daerah Sekolah Tinggi Teknologi Minyak dan Gas Bumi Balikpapan sehingga membuat energi yang bisa diserap oleh sel surya menjadi lebih sedikit daripada pada saat cuaca cerah. Berikut pada Gambar 7 dan Gambar 8 adalah menunjukkan cuaca pada saat pengambilan data.

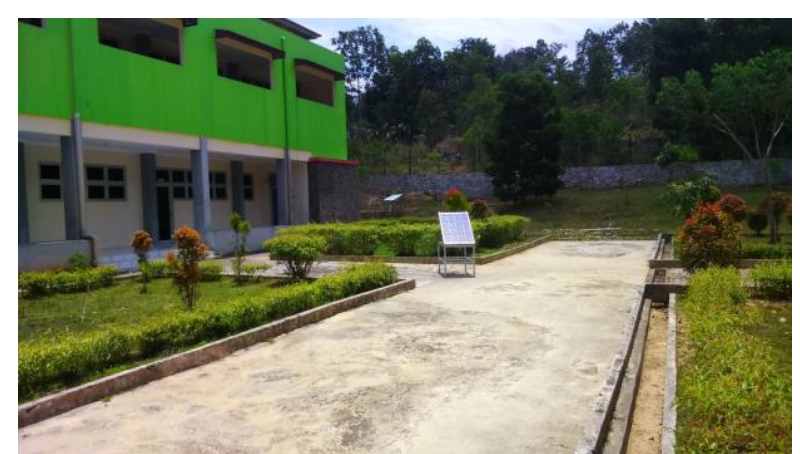

Gambar 7. Pengambilan Data pada saat Cuaca Cerah

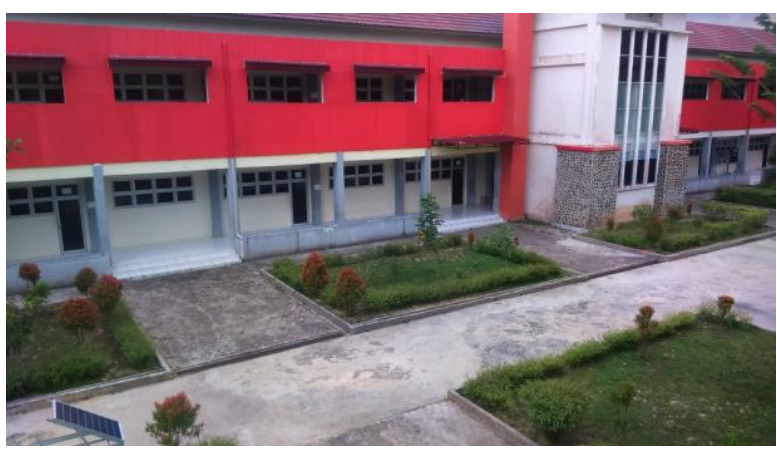

Gambar 8. Pengambilan Data pada saat Cuaca Mendung 


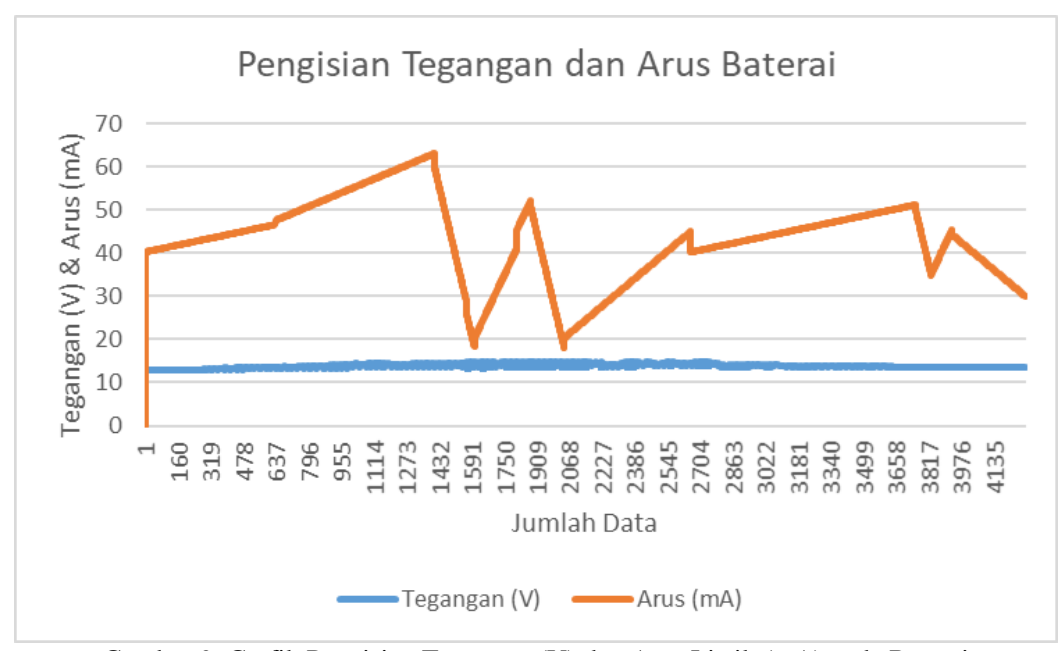

Gambar 9. Grafik Pengisian Tegangan (V) dan Arus Listik (mA) pada Baterai

Pada Gambar 9 dapat dilihat bahwa garis yang berwarna biru adalah tegangan dalam satuan voltage (V) sedangkan garis yang berwarna oranye adalah arus dalam satuan mili Ampere (mA). Dapat dilihat pada tegangan bahwa tegangan mengalami sedikit perubahan. Hal ini dikarenakan bahwa arus yang mengalir dari sel surya menuju baterai sangatlah kecil. Pada Gambar 9 dapat dilihat arus listrik yang paling besar adalah $60 \mathrm{~mA}$ dan butuh waktu lama untuk mengisi seluruh kapasitas baterai yaitu $100 \mathrm{Ah}$. Dari hasil perhitungan yang telah dilakukan bahwa dibutuhkan waktu 1 tahun lebih atau sekitar 14 bulan agar baterai penuh. Oleh karena itu, dalam hal ini digunakan MATLAB sebagai salah satu langkah untuk mensimulasikan pengisian baterai tersebut dengan data yang telah didapatkan. Model simulasi yang terlihat pada Gambar 10 adalah hasil dari desain Penulis dimana Penulis membuat model sesuai dengan kenyataan.

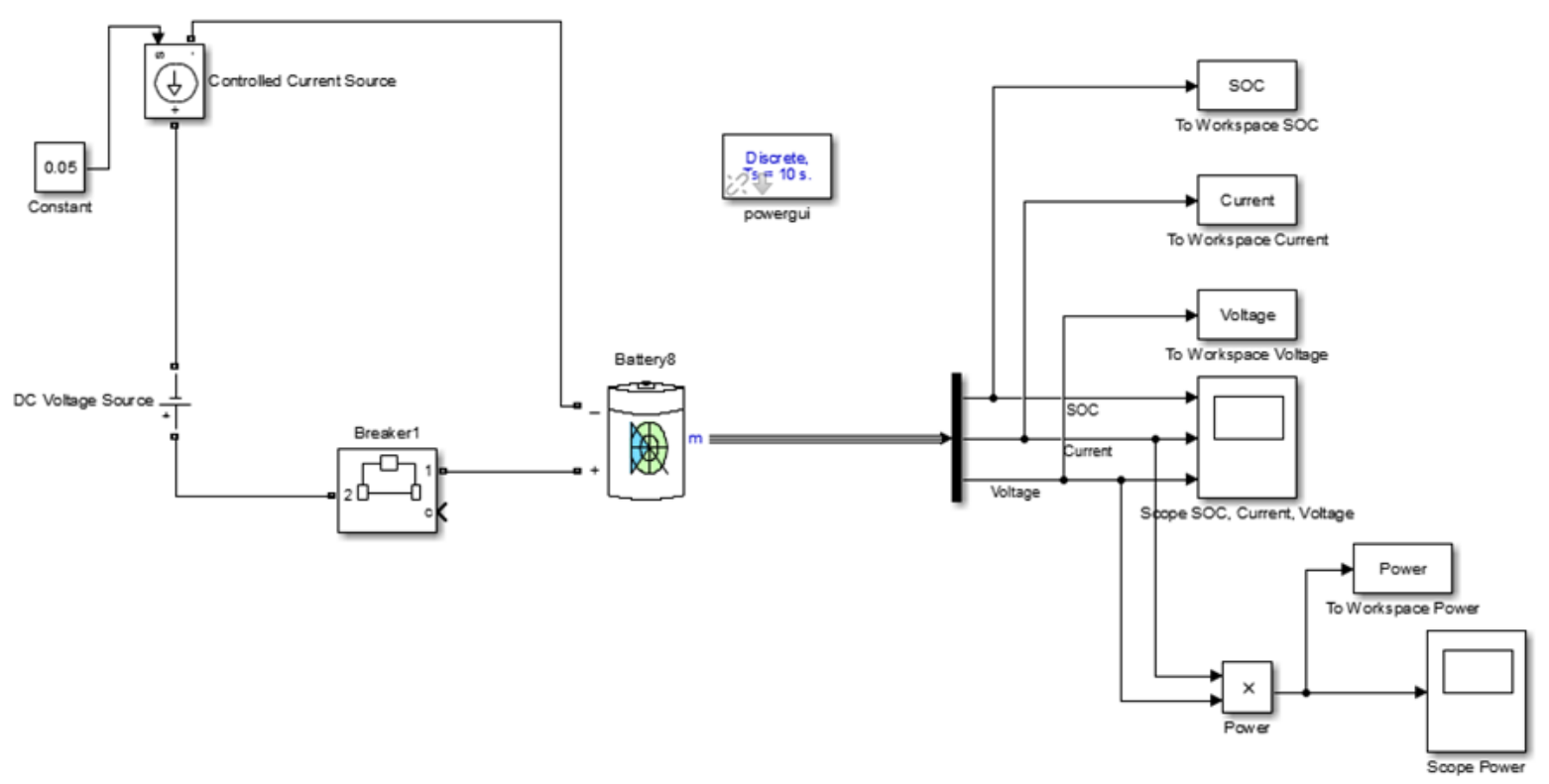

Gambar 10. Sistem Pengisian Baterai menggunakan SIMULINK

Baterai diatur pada kondisi awal SOC (State-of-Charge) adalah 20\% dimana tegangan pada nilai tersebut adalah 10,5 V. Dari pengaturan tersebut, maka simulasi dijalankan selama 14 bulan atau 1 tahun lebih dengan arus konstan 0,05 A seperti hasil yang dapat dilihat pada Gambar 11. 


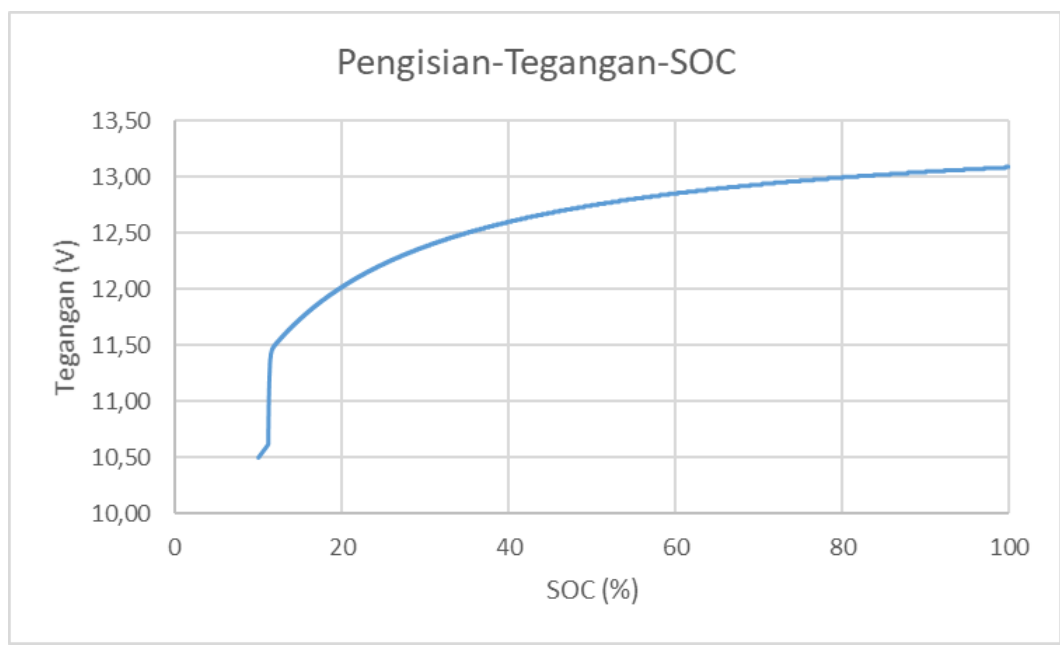

Gambar 11. Grafik Hasil Pengisian Tegangan terhadap SOC pada SIMULINK

Untuk pengosongan baterai, dilakukan selama 3 hari (3 kali pengambilan data) untuk menyalakan dua buah lampu pijar 60 watt selama kurang lebih 6 jam dengan arus listrik yang keluar adalah $105 \mathrm{~mA}$. Berikut pada Gambar 12 adalah hasil dari pengosongan baterai yang telah dilakukan.

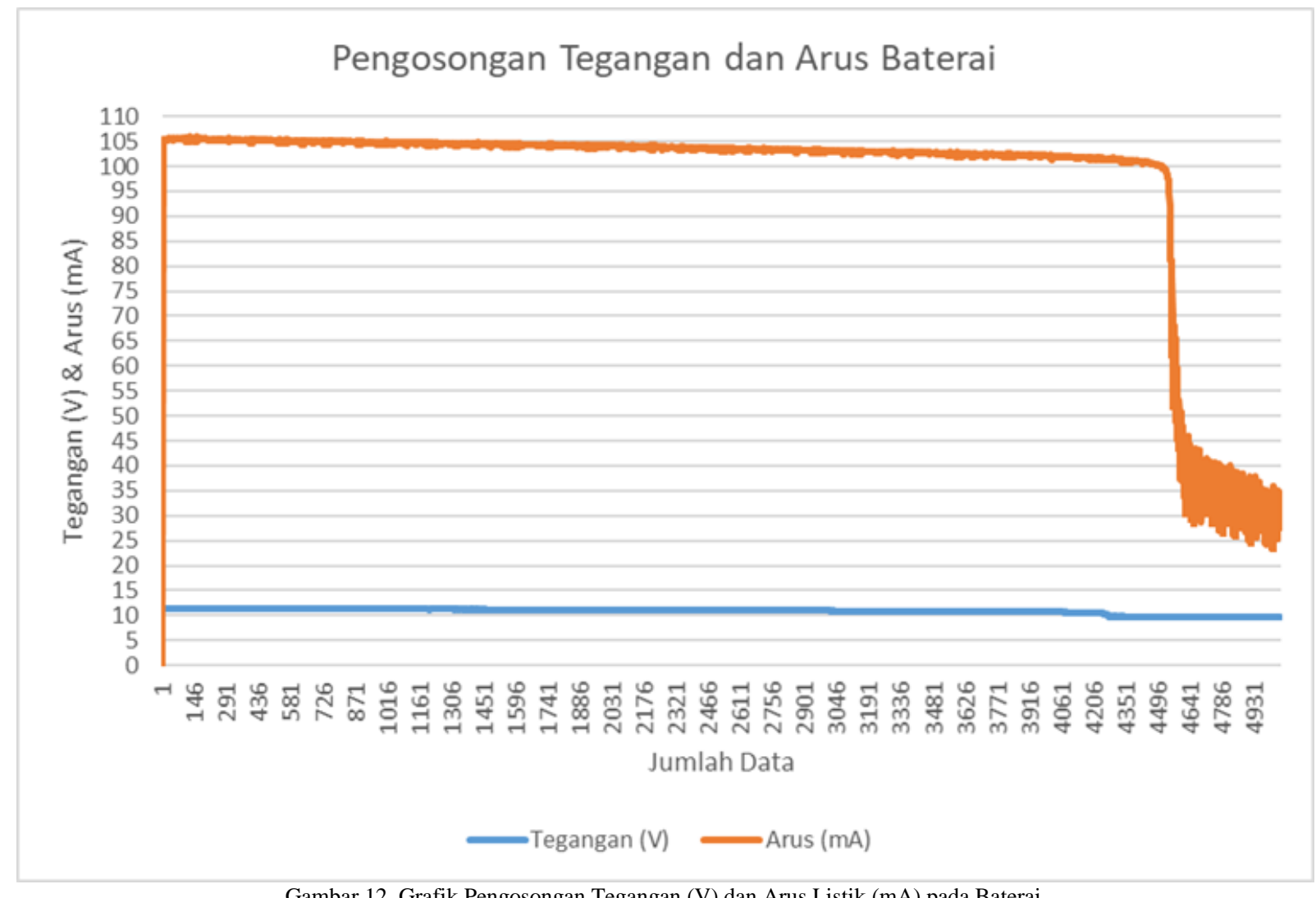

Gambar 12. Grafik Pengosongan Tegangan (V) dan Arus Listik (mA) pada Baterai

Hasil dari Gambar 12 adalah bahwa arus listrik yang keluar berjalan dengan konstan. Hal ini dikarenakan bahwa lampu pijar membutuhkan arus listrik yang sudah ditetapkan sehingga beban bersifat diskrit.

Sama seperti halnya pengisian, bahwa dalam pengosongan juga menggunakan SIMULINK untuk memperoleh data yang disimulasikan selama 14 bulan. Berikut pada Gambar 13 adalah sistem pengosongan baterai menggunakan SIMULINK. 


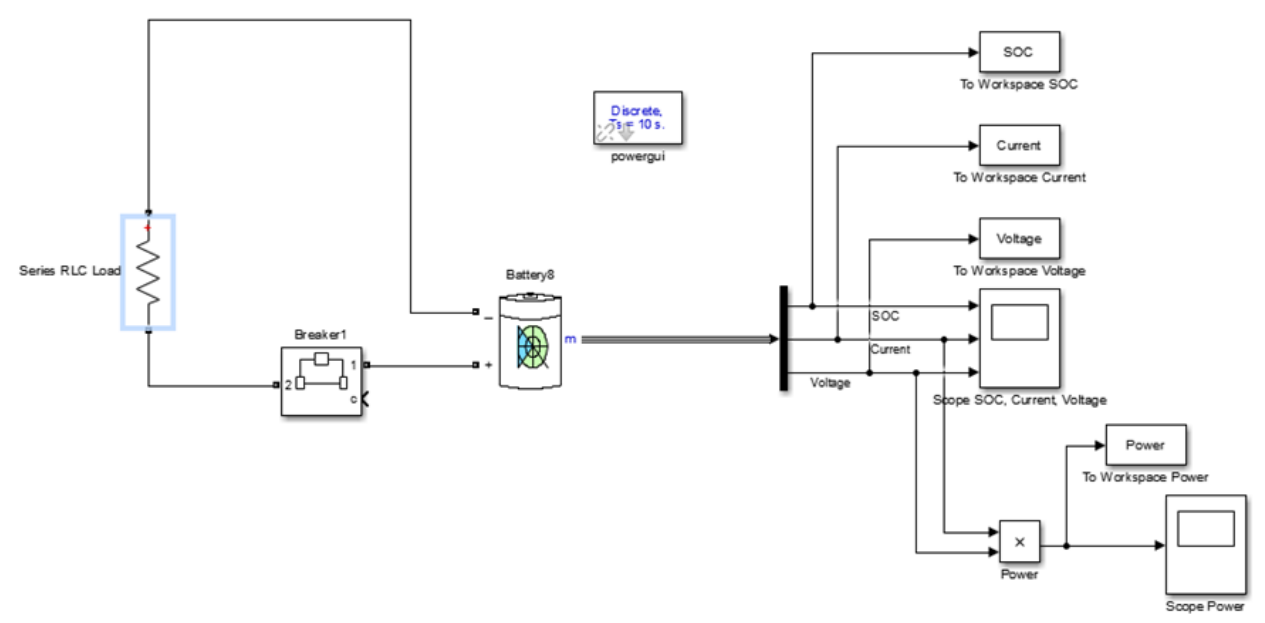

Gambar 13. Sistem Pengosongan Baterai menggunakan SIMULINK

Baterai diatur pada kondisi awal SOC adalah 100\% dengan asumsi kondisi penuh dimana tegangan pada nilai tersebut adalah 13,1 V. Dari pengaturan tersebut, maka simulasi dijalankan selama 14 bulan atau 1 tahun lebih dengan arus konstan 0,05 A seperti hasil yang dapat dilihat pada Gambar 14.

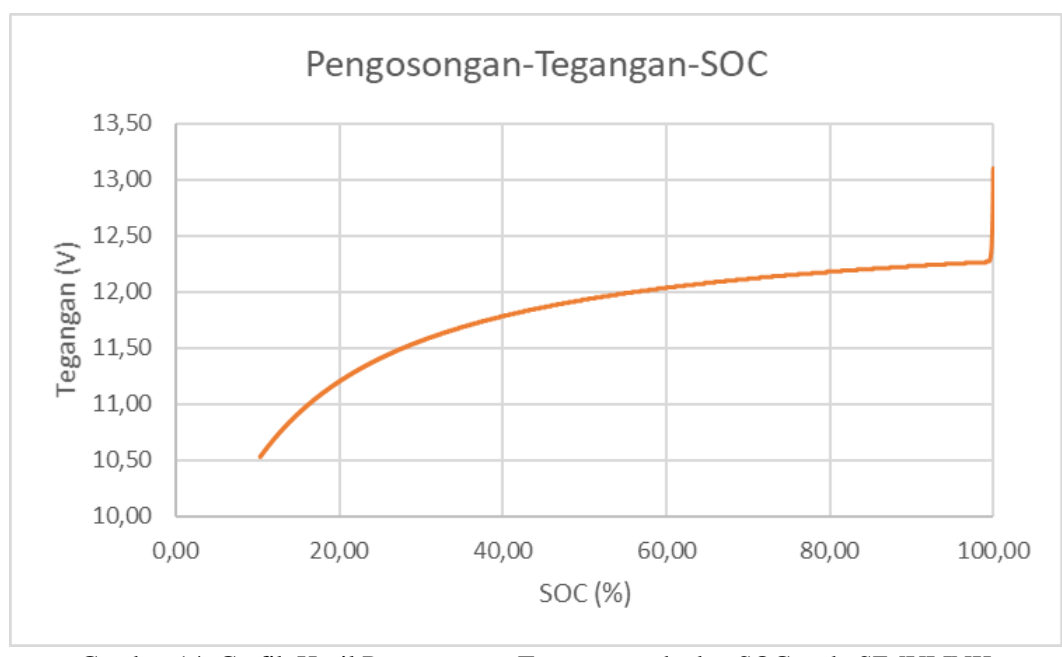

Gambar 14. Grafik Hasil Pengosongan Tegangan terhadap SOC pada SIMULINK

Berbeda dengan pengisian, pada Gambar 14 dapat diketahui bahwa baterai mulai konstan bekerja pada SOC 30\% - 90\% dan terjadi penurunan drastis pada SOC 100\% ke 90\%. Hal ini dikarenakan bahwa baterai baru akan bekerja secara maksimal pada rentang SOC 30\% - 90\%.

\section{KESIMPULAN}

Dari penelitian ini dapat disimpulkan bahwa besarnya tegangan dan arus listrik yang didapatkan dari sel surya tergantung pada cuaca cerah atau mendung. Namun jika mendung pun, sel surya tetap bisa mengisi ke baterai dengan waktu yang lama. Oleh karena itu, dalam penelitian ini ada dua hal yang dapat disimpulkan yaitu sel surya dan baterai. Untuk sel surya, diperlukan tenaga sel surya yang lebih dari 100 WP agar baterai terisi lebih cepat. Untuk baterai dapat menggunakan baterai jenis deep cycle dimana baterai yang digunakan dalam penelitian ini adalah baterai jenis otomotif. Untuk kesimpulan dari SOC bahwa SOC akan bekerja pada rentang $30 \%$ sampai dengan $90 \%$ dengan asumsi baterai yang digunakan masih dalam keadaan baru.

\section{DAFTAR PUSTAKA}

[1] J. Pasaribu, "Pengaruh Pertumbuhan Penduduk, Pertumbuhan Industri, dan Belanja Subsidi Listrik Terhadap Permintaan Energi Listrik dan Pertumbuhan Ekonomi di Indonesia," Final Proj., 2018.

[2] D. Prianjani and W. Sutopo, "Studi Komparasi Penelitian Standar Kendaraan Listrik Dunia Dengan Standar Kendaraan Listrik 
Indonesia," Pros. SNST ke-9, pp. 179-191, 2018.

[3] M. Fahmi Hakim, "Perancangan Rooftop Off Grid Solar Panel Pada Rumah Tinggal Sebagai Alternatif Sumber Energi Listrik," Din. DOTCOM, vol. 8, 2017.

[4] M. Majidi, S. Nojavan, and K. Zare, "Optimal stochastic short-term thermal and electrical operation of fuel cell/photovoltaic/battery/grid hybrid energy system in the presence of demand response program," Energy Convers. Manag., vol. 144, pp. 132-142, 2017.

[5] D. Kikinis, "Method and system for connecting solar cells or slices in a panel system," Google Patents US9218013B2, 2015.

[6] B. Diouf and R. Pode, "Potential of lithium-ion batteries in renewable energy," Renew. Energy, vol. 76, pp. 375-380, 2015.

[7] L. Zhao, H. Li, G. Ji, and Z. Liu, "A Robust Estimation of State of Charge for Electric Vehicle Batteries," IFAC-PapersOnLine, vol. 51, no. 31 , pp. $279-284,2018$

[8] I. Haq, R. Saputra, F. Edison, D. Kurniadi, E. Leksono, and B. Yulianto, "State of charge (SoC) estimation of LiFePO4 battery module using support vector regression," Proc. Jt. Int. Conf. Electr. Veh. Technol. Ind. Mech. Electr. Chem. Eng. (ICEVT IMECE) 2015, pp. $16-21,2015$.

[9] C. Zhang, F. Yan, C. Du, and G. Rizzoni, "An Improved Model-Based Self-Adaptive Filter for Online State-of-Charge Estimation of Li-Ion Batteries," Appl. Sci., 2018.

[10] A. Nugroho, E. Rijanto, D. F. Wijaya, and P. Nugroho, "Battery state of charge estimation by using a combination of Coulomb Counting and dynamic model with adjusted gain," Int. Conf. Sustain. Energy Eng. Appl. Sustain. Energy Gt. Dev. ICSEEA 2015, pp. 54-58, 2015.

[11] E. Tudoroiu, M. Zaheeruddin, S. M. Radu, and N. Tudoroiu, "Estimation Techniques for State-of-Charge in Battery Management Systems on-board of Hybrid Electric Vehicles Implemented in a Real-Time MATLAB," intechopen.com, 2018. 